\title{
NEW RECORDS OF Orasema xanthopus \\ (HYMENOPTERA: EUCHARITIDAE) AND Solenopsis daguerrei (HYMENOPTERA: FORMICIDAE) FROM BRAZIL
}

\author{
PESQUERO, M. A. and PENTEADO-DIAS, A. M. \\ Departamento de Ecologia e Biologia Evolutiva, Universidade Federal de São Carlos, Rodovia Washington Luís, \\ km 235, CEP 13565-905, São Carlos, SP, Brazil \\ Correspondence to: Marcos A. Pesquero, Departamento de Ecologia e Biologia Evolutiva, Universidade Federal \\ de São Carlos, Rodovia Washington Luís, km 235, CEP 13565-905, São Carlos, \\ SP, Brazil, e-mail: ppesq@iris.ufscar.br
}

Received February 18, 2003 - Accepted June 27, 2003 - Distributed August 31, 2004

The Eucharitidae Orasema xanthopus (Cameron) and the ant Solenopsis daguerrei (Santschi) are natural enemies of the fire ants Solenopsis. The first species is a parasitoid of $S$. invicta Buren and Solenopsis sp. saevissima-complex (Heraty, 1994); the other is a social parasite of $S$. invicta, $S$. macdonaghi (Santschi) (Briano et al., 1997), and $S$. richteri Forel (Silveira-Guido et al., 1973). These two species are native to South America and have been considered as potential control agents of the fire ant $S$. invicta introduced 70 years ago into the USA (Wojcik, 1986). The objective of this study is to amplify the knowledge of the geographical distribution of these insects in Brazil, as well as to verify their association with $S$. saevissima (Fr. Smith). Hundreds of fire ant nests were opened in 2001 in $S$. saevissima and $S$. invicta territories (Goiás and São Paulo states) in order to determine whether or not these natural enemies were present. Only adult individuals were considered. Complementary data on geographical distribution were obtained in collection references. Several individuals of $O$. xanthopus and $S$. daguerrei were collected with an aspirator and preserved in $70 \%$ alcohol. The fire ant species were identified using Trager's key (1991). O. xanthopus and $S$. daguerrei were identified using the key of Heraty et al. (1993), and the Briano et al. (1997) material comparison, respectively. Six females of $O$. xanthopus were observed attacking two colonies of S. saevissima [Goiânia, GO $\left(17^{\circ} \mathrm{S}, 49^{\circ} \mathrm{W}\right)$ and Luiz Antônio, SP $\left.\left(21^{\circ} \mathrm{S}, 48^{\circ} \mathrm{W}\right)\right]$. Reference data of collections show that this species also occurs in Descalvado, SP $\left(22^{\circ} \mathrm{S}, 47^{\circ} \mathrm{W}\right)$. Several males and winged queens of $S$. daguerrei were observed in only one $S$. invicta colony in Anhembi, SP $\left(23^{\circ} \mathrm{S}, 48^{\circ} \mathrm{W}\right)$. Both species of natural enemies were rare compared with Pseudacteon parasitoid occurence (Pesquero and Penteado-Dias, unpublished). The inclusion of $S$. saevissima in the host list of $O$. xanthopus extends its distribution into the territory of this fire ant species. Apparently, $S$. daguerrei does not use $S$. saevissima as a host, and is principally limited to $S$. invicta territory.

Acknowledgements - We thank C. R. Brandão (Museu de Zoologia da Universidade de São Paulo), and A. E. CamposFarinha (Instituto Biológico) for access to the insect reference collections. The collections of Eucharitidae were carried out by K. R. N. Cirelli in Descalvado, and J. M. Heraty supplied collection material and an identification key for Orasema. This research was supported by Fapesp.

\section{REFERENCES}

BRIANO, J. A., CALCATERRA, L. A., WOJCIK, D. P., WILLIAMS, D. F., BANKS, W. W. \& PATTERSON, R. S., 1997, Abundance of the parasitic ant Solenopsis daguerrei (Hymenoptera: Formicidae) in South America, a potential candidate for the biological control of the red fire ant in the United States. Environ. Entomol., 26: 1143-1148.

HERATY, J. M., 1994, Biology and importance of two Eucharitidae parasites of Wasmannia and Solenopsis, pp. 104-120. In: D. F. Williams (ed.), Exotic ants: biology, impact, and control of introduced species. Westview Press, Boulder.

HERATY, J. M., WOJCIK, D. P. \& JOUVENAZ, D. P., 1993, Species of Orasema parasitic on the Solenopsis saevissimacomplex in South America (Hymenoptera: Eucharitidae, Formicidae). J. Hym. Res., 2: 169-182.

SILVEIRA-GUIDO, A., CARBONELL, J. \& CRISCI, C., 1973, Animals associated with the Solenopsis (fire ants) complex, with special reference to Labauchena daguerrei. Proc. Tall. Timbers Conf. Ecol. Anim. Control Habitat. Manage, 4: 41-52.

TRAGER, J. C., 1991, A revision of the fire ants, Solenopsis geminata group (Hym., Formicidae: Myrmicinae). J. New York Entomol. Soc., 99: 141-198.

WOJCIK, D. P., 1986, Observations on the biology and ecology of fire ants in Brazil, pp. 88-103. In: C. S. Lofgren \& R. K. Vander Meer (eds.), Fire ants and leaf-cutting ants, biology and management. Westview Press, Boulder. 